\title{
IMPLEMENTASI APLIKASI QUIZIZZ PADA MATERI JARINGAN TUMBUHAN
}

\author{
Ambar Ismara Mula Darisman ${ }^{1}$, Purwati Kuswarini Suprapto ${ }^{\mathbf{1}}$, Rinaldi Rizal Putra ${ }^{1}$ \\ Jurusan Pendidikan Biologi, Fakultas Keguruan dan Ilmu Pendidikan, Universitas Siliwangi. \\ Jalan Siliwangi No. 24 Kota Tasikmalaya 46115 Jawa Barat \\ IsmaraMD@gmail.com
}

\section{Naskah diterima 22 Oktober 2020 dan disetujui 29 Oktober 2020}

\begin{abstract}
This study aims to see the effect of the quiz application on student learning outcomes on tissue material in plants in class XI MIPA one of the high schools located on the border of Garut Regency. This research was conducted from August 2019 to September 2019. The research method used was a quasiexperimental research design with the nonequivalent control group design. The population in this study were all class XI MIPA in 2019-2020. The sample used is two classes taken with positive sampling technique. The active data technique is in the form of a learning outcome test that is carried out before and after the learning process takes place. The instrument used was a test of learning outcomes on plant tissue material as many as 35 multiple-choice questions. The research data were analyzed using t-test. This study found an increase in the cognitive aspects of learning outcomes, especially at the level of analysis, this increase occurred because this application was combined with practicum activities. Besides, students' cheating habits can be reduced because students are used to working on questions using randomized applications. So that based on the results of the research it can be revealed that there is an effect of the Quizizz application on student learning outcomes on plant tissue material.
\end{abstract}

Kata kunci: Quizizz application; learning outcomes; plant tissue

\section{PENDAHULUAN}

Pendidikan merupakan usaha untuk mengembangkan potensi yang dimiliki seseorang baik itu melalui proses pembelajaran maupun cara lain yang dikenal ataupun diakui oleh masyarakat (Abdurahman, 2017). Saat ini, kita masih melihat metode pembelajaran yang masih konvensional berlangsung di beberapa lembaga pendidikan. Dimana pendidik ditempatkan pada posisi "serba bisa", yang memiliki tugas mentransfer ilmu pengetahuan. Sedangkan peserta didik adalah mesin penerima ilmu pengetahuan yang tidak boleh membantah (Andaryuni, 2014). Dalam pembelajaran seperti ini, hanya akan menghasilkan proses pembelajaran yang terkesan monoton, membosankan dan membuat peserta didik tidak nyaman berada di dalam kelas untuk menerima pembelajaran. Keberhasilan pembelajaran khususnya pembelajaran biologi dapat diukur dari tingkat penguasaan materi, serta hasil belajar peserta didik. Semakin tinggi tingkat penguasaan suatu materi serta hasil belajar, maka semakin tinggi pula tingkat keberhasilan pembelajaran.

Berdasarkan hasil pengamatan peneliti, masalah yang timbul di sekolah ini adalah kebiasaan peserta didik dalam mengerjakan pekerjaan rumahnya yang cenderung menyalin pekerjaan orang lain tanpa memahami isi dari pekerjaan tersebut. Hal ini terlihat ketika peserta didik diminta mengerjakan tugasnya di papan tulis atau menjawab secara lisan dengan persoalan yang sama, dan peserta didik tersebut tidak bisa mengerjakan atau menjawabnya seperti yang dia kerjakan di rumah. Ini akan berdampak pada kemampuan penguasaan materi peserta didik tersebut karena pendidik tidak mengetahui peserta didik yang mengerjakan pekerjaan rumah dengan sungguh-sungguh dan yang hanya menyalin pekerjaan orang lain.

Untuk mengatasi masalah tersebut diperlukan tindak lanjut dari pekerjaan 
rumah yang diberikan pendidik untuk meningkatkan hasil belajar peserta didik. Salah satunya yaitu dengan pemberian kuis (Side, 2017) diawal pertemuan sebelum pembelajaran dilakukan (Riskawati, 2017), sehingga peserta didik akan mengerjakan pekerjaan rumah secara sungguh-sungguh sebagai persiapan untuk menghadapi kuis yang hasilnya akan meningkatkan pada hasil peserta didik dan pemberian kuis di akhir pertemuan untuk melihat perkembangan pemahaman peserta didik setelah mengikuti pembelajaran (Setyanta, 2012).

Hasil belajar peserta didik yang belajar di kelas dengan pemberian kuis diawal pertemuan menunjukan bahwa hasilnya lebih baik dibandingkan dengan kelas yang tidak diberikan kuis diawal pertemuannya (Sumiati, 2017), dengan memberikan kuis pada pertemuanpertemuan tertentu, peserta didik akan lebih bersemangat, bersungguh- sungguh atau lebih aktif dalam mengikuti pembelajaran (Sari, 2018). Pemberian kuis ini diharapkan dapat mendorong peserta didik dalam mempersiapkan diri di rumah untuk belajar sebelum masuk kelas.

Untuk meningkatkan minat peserta didik terhadap pemberian kuis yang dilakukan oleh pendidik, maka harus diiringi dengan penggunaan media yang inovatif. Saat ini banyak developer yang menyediakan berbagai aplikasi dengan kelebihannya, salah satunya adalah aplikasi Quizizz yang memberikan suasana bermain game saat menjawab soal-soal kuis yang diberikan (Rohwati, 2012). Aplikasi Quizizz ini adalah sebuah web tool (Bahar, 2017) penyedia layanan game untuk bemain kuis berbasis Online yang dapat dimasukan kedalam proses belajar mengajar karena aplikasi ini memberikan akses penuh untuk membuat setiap pertanyaannya (Shamil, 2019). Peserta didik mengerjakan kuis secara mandiri namun seolah-olah sedang bermain bersama karena dalam Quizizz terdapat elemen- elemen yang menarik seperti penggunaan avatar, leaderboard, dan meme yang bersifat lucu. Pendidik dapat menganalisis laporan kemajuan peserta didiknya melalui data yang diperoleh dari statistik pengerjaan kuis dan dapat membantu pendidik menemukan materi yang dianggap lemah. Seperti yang telah dilakukan (Mei, 2018) bahwa dengan menggunakan aplikasi Quizizz berhasil untuk menarik minat belajar dan membuat kelas lebih fokus pada materi pembelajaran. Berdasarkan deskripsi tersebut, penulis tertarik melakukan penelitian mengenai "Implementasi Aplikasi Quizizz pada materi jaringan tumbuhan"

\section{METODE PENELITIAN}

Metode penelitian yang digunakan adalah quas iexperiment, bentuk desain eksperimen ini merupakan pengembangan dari true experiment design, yang sulit dilaksanakan. Desain ini mempunyai kelompok kontrol, tetapi tidak dapat berfungsi sepenuhnya untuk mengontrol variabel-variabel luar yang memengaruhi pelaksanaan eksperimen. Walaupun demikian desain ini lebih baik dari preexperimen design. Quasi experimen design digunakan karena pada kenyataannya sulit mendapatkan kelompok kontrol yang digunakan untuk penelitian (Arikunto, 2018).

Populasi dalam penelitian ini adalah seluruh peserta didik kelas XI MIPA tahun pelajaran 2019-2020. Sampel dalam penelitian ini diambil dengan menggunakan teknik purposive sampling. Instrumen penelitian yang digunakan dalam penelitian ini adalah tes tertulis dalam bentuk pilihan majemuk dengan lima alternatif pilihan sebanyak 35 soal. Aspek yang diukur dalam penelitian ini yaitu dimensi pengetahuan faktual (K1), pengetahuan konseptual (K2), pengetahuan prosedural (K3), serta dibatasi pada jenjang mengingat $(\mathrm{C} 1)$, memahami (C2), mengaplikasikan (C3), menganalisis (C4) dan mengevaluasi (C5).

Desain penelitian yang digunakan dalam penelitian ini adalah Nonequivalent Control Group Design. Menurut (Sugiyono, 2018) desain ini merupakan pengembangan dari true experiment yang sulit dilaksanakan. Desain ini hampir sama dengan pretest- 
posttest control group design, hanya pada desain ini kelompok eksperimen maupun kelompok kontrol tidak dipilih secara random. Pengaruh perlakuan adalah

$$
\begin{aligned}
& \text { (O2-O1)-(O4-O3). } \\
& \begin{array}{ccc}
\text { O1 } & \text { X } & \text { O2 } \\
\hline \text { O3 } & \text { C } & \text { O4 }
\end{array}
\end{aligned}
$$

Data dianalisis dengan menggunakan prasyarat analisis dan uji hipotesis. Uji normalitas dianalisis dengan Uji $C h i$ Kuadrat $\left(\chi^{2}\right)$ dan uji homogenitas dianalisis dengan uji $\mathrm{F}_{\text {maksimum. Hipotesis dianalisis }}$ dengan menggunakan Uji t.

\section{HASIL DAN PEMBAHASAN}

Data yang diperoleh dari penelitian ini adalah pretest dan posttest kelas kontrol dan kelas eksperimen. Berdasarkan hasil uji prasyarat analisis yang telah dilakukan, seluruh data memenuhi prasyarat analisis yaitu data berasal dari populasi yang berdistribusi normal dan varians homogen,

\begin{tabular}{|c|c|c|c|c|}
\hline t & & & & \\
\hline thitung & ttabel & $\begin{array}{c}\text { Hasil } \\
\text { Analisis }\end{array}$ & $\begin{array}{c}\text { Kesim } \\
\text { pulan }\end{array}$ & $\begin{array}{c}\text { Kesimpul } \\
\text { an } \\
\text { Analisis }\end{array}$ \\
\hline$-116,35$ & $\begin{array}{c}2,03 \\
6\end{array}$ & $\begin{array}{c}\text { thitun } \\
\text { g< } \\
\text { ttabe } \\
\text { l }\end{array}$ & $\begin{array}{c}\text { Tolak } \\
\text { Ho }\end{array}$ & $\begin{array}{c}\text { Pretest } \neq \\
\text { posttest }\end{array}$ \\
\hline$-17,68$ & $\begin{array}{c}2,03 \\
6\end{array}$ & $\begin{array}{l}\text { thitung } \\
<\end{array}$ & $\begin{array}{c}\text { Tolak } \\
\text { Ho }\end{array}$ & $\begin{array}{c}\text { Pretest } \neq \\
\text { postest }\end{array}$ \\
\hline 4,13 & $\begin{array}{c}2,02 \\
2\end{array}$ & $\begin{array}{l}\text { t*hitung } \\
> \\
\text { t*tabel }\end{array}$ & $\begin{array}{c}\text { Tolak } \\
\text { Ho }\end{array}$ & $\begin{array}{c}\text { Terdapat } \\
\text { pengaruh } \\
\text { aplikasi } \\
\text { Quizizz } \\
\text { terhadap } \\
\text { hasil } \\
\text { belajar }\end{array}$ \\
\hline
\end{tabular}
tetapi uji homogenitas yang dilakukan pada skor $\mathrm{N}$-gain kelas eksperimen dan kelas kontrol memiliki nilai varians yang tidak homogen. Uji t dan uji t* digunakan untuk menguji hipotesis yang diajukan dalam penelitian. Uji hipotesis dilakukan karena data telah memenuhi uji prasyarat analisis. Ringkasan hasil uji t dan uji t* disajikan pada Tabel 1. Sebagai berikut.
Tabel 1 Ringkasan Hasil Uji

Tabel 1 menunjukan ringkasan hasil uji $\mathrm{t}$ dan uji $\mathrm{t}^{*}$ bahwa hasil analisis $\mathrm{t}_{\text {hitung }}$ lebih besar daripada $\mathrm{t}_{\text {tabel }}$ maka $\mathrm{H}_{0}$ ditolak. Sehingga pada tingkat kepercayaan 95\% dapat disimpulkan bahwa aplikasi Quizizz berpengaruh terhadap hasil belajar peserta didik. Setelah dilakukan uji t untuk mengetahui pengaruh dari aplikasi tersebut, dilihat pula berdasarkan perbandingan hasil rata-rata skor pretes, posttest dan $\mathrm{N}$-gain yang dapat dilihat pada gambar berikut:

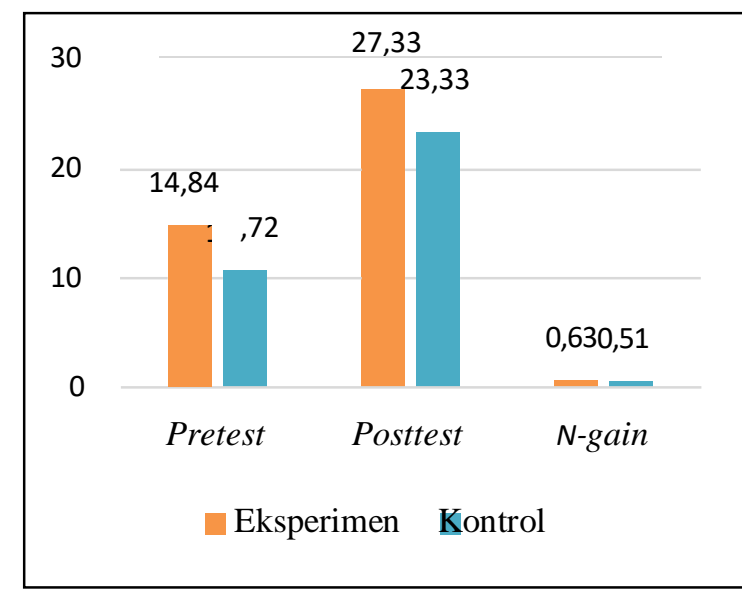

Gambar 1. Diagram Batang Perbandingan Rata-rata Pretest, Posttest dan $\mathrm{N}$-gain Kelas Kontrol dan Eksperimen

Gambar 1 menunjukan bahwa kelas eksperimen yang diberikan kuis dengan aplikasi Quizizz memperoleh skor lebih tinggi dibandingkan dengan kelas kontrol 
yang tidak diberikan kuis. Hal ini memuktukan bahwa pembelajaran dengan pemberian kuis dalam aplikasi Quizizz dapat meningkatkan hasil belajar peserta didik (Sumiati, 2017).

Hal tersebut disebabkan karena aplikasi Quizizz membuat peserta didik mengingat lebih lama tentang pelajaran karena diulang kembali dalam bentuk soalsoal dan menuntut peserta didik untuk terus bersaing dalam leaderboard sehingga membuat peserta didik lebih aktif dalam mengikuti pembelajaran dan dapat meningkatkan hasil belajar peserta didik (Sari, 2018). Sejalan dengan penelitian yang dilakukan oleh (Mei, 2018) bahwa "dengan menggunakan aplikasi Quizizz berhasil menarik minat belajar dan membuat kelas lebih fokus pada materi pembelajaran yang dapat meningkatkan hasil belajar peserta didik".

Adapun berdasarkan perolehan skor $\mathrm{N}$ - gain kelas kontrol dan kelas eksperimen yang terdiri dari 35 soal pilihan majemuk dapat dilihat pada diagram berikut ini:

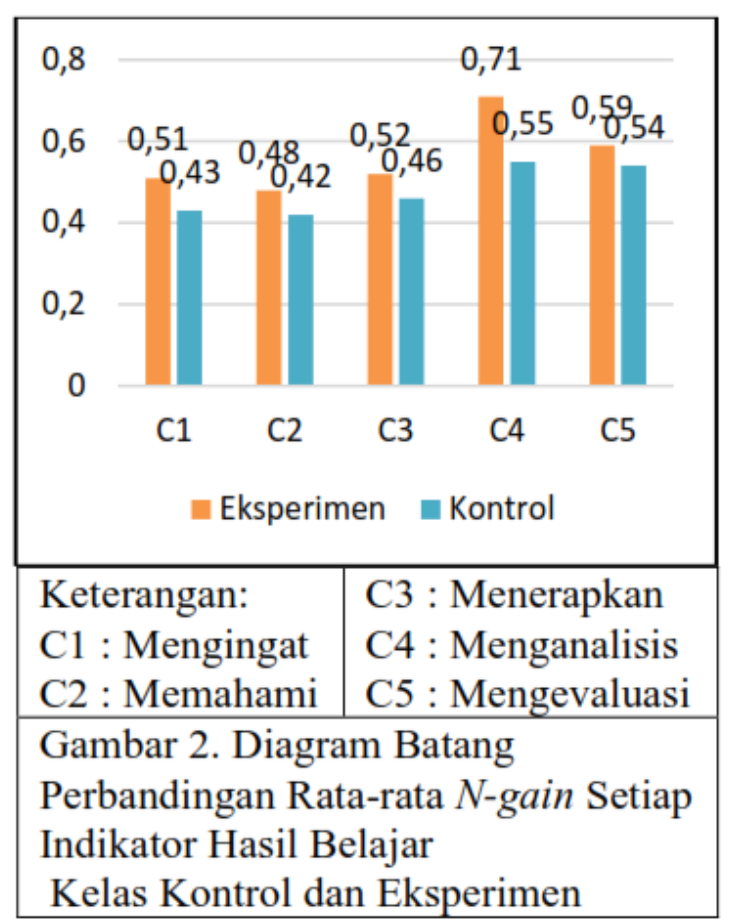

Berdasarkan gambar 2 diatas dapat dilihat bahwa nilai perbandingan $N$-gain dari kedua kelas memiliki perbedaan yang signifikan pada indikator menganalisis, kelas eksperimen memiliki nilai $N$-gain yang sangat tinggi dibandingkan kelas kontrol. Indikator menganalisis mengalami peningkatan dalam kategori tinggi. Sedangkan indikator mengingat, memahami, menerapkan dan mengevaluasi mengalalami peningkatan dalam kategori sedang.

Pada kelas eksperimen indikator menganalisis dengan nilai $N$-gain sebesar 0,71 termasuk kategori tinggi. Hal ini menunjukan bahwa dengan diterapkannya pemberian kuis dengan aplikasi Quizizz. pada proses pembelajaran, dapat mengarahkan peserta didik untuk mengembangkan kemampuan menganalisis karena pada pelaksanaan pembelajarannya pemberian kuis ini dikombinasikan dengan praktikum sehingga kemampuan analisis peserta didik lebih mendalam dengan diberikannya soal- soal yang menganalisis hasil praktikum. Sejalan dengan diterapkannya pemberian kuis menggunakan aplikasi Quizizz ditemukan beberapa kelebihan diantaranya peserta didk tidak lagi bergantung kepada orang lain karena didalam kuis ini peserta didik tidak bisa bekerja sama dengan peserta yang lain, karena peserta didik menerima urutan soal yang berbeda-beda, kemudian peserta didik lebih senang karena layout yang diberikan aplikasi quizizz ini menarik tetapi mudah dimengerti karena mengorientasi pada sebuah game online yang banyak dikenal dikalangan peserta didik jenjang SMA, selain itu peserta didik lebih bersaing secara sehat karena peringkat yang diterima peserta didik ditayangkan di dalam leaderboard sehingga peserta didik terpacu untuk bersaing untuk menjadi peringkat tertinggi dalam setiap putaran dalam kuis ini (Bahar, 2017). Sedangkan kelemahan dari aplikasi Quizizz ini dalam pelaksanaannya membutuhkan waktu yang lama, sedangkan waktu yang tersedia terbatas sehingga beberapa indikator belum berkembang secara optimal, kemudian dalam pelaksanaannya memerlukan akses internet yang stabil selain itu diperlukan spesifikasi gawai yang cukup tinggi untuk mengakses 
aplikasi Quizizz ini.

\section{KESIMPULAN}

Berdasarkan hasil analisis data dan pengujian hipotesis, maka diperoleh simpulan terdapat pengaruh aplikasi Quizizz terhadap hasil belajar peserta didik pada materi jaringan tumbuhan dikelas XI MIPA tahun ajaran 2019-2020. Temuan pada penelitian ini menunjukan bahwa aplikasi Quizizz dapat meningkatkan indikator menganalisis, selama proses pembelajaran peserta didik menjadi lebih aktif, berinteraksi antar peserta didik maupun guru, diskusi dan menunjukan pendapat.

\section{DAFTAR PUSTAKA}

Abdurahman. (2017) Implikasi UUSPN Terhadap Pendidikan Islam. $A l$ Tanzim. 1(1). 19-35.

Andaryuni, Lilik. (2014) Pendidikan Multikultural di Perguruan Tinggi (Studi Terhadap STAIN Samarinda). Fenomena. 6 (1). 55-64.

Arikunto, Suharsimi. (2013). Prosedur Penelitian Suatu Pendekatan Praktik Jakarta: Rineka Cipta.

Ayunara, Bahar. (2017). Membuat Kuis Interaktif Kelas dengan Quizizz.[Online], Tersedia : http://www.ahzaa.net/2017/08/membu at- kuis-interaktif-kelas-dengan.html (diakses 3 Februari 2019)

Mei, S. Y., Ju S. Y., Adam, Zalika. (2018). Implementing Quizizz as Game Based Learning in the Arabic Classroom. European Journal of Social Sciences Education and Research. 12 (1). 208212.

Riskawati. (2017). Pengaruh Pemberian Kuis pada Proses Pembelajaran Fisika Terhadap Hasil Belajar Peserta Didik Kelas XI SMKN 4 Bulukumba. Jurnal Pendidikan Fisika Universitas Muhammadiyah Makassar. 5(1). 9098.

Rohwati, M. (2012). Penggunaan Education Game untuk Meningkatkan Hasil Belajar IPA Biologi Konsep Klasifikasi Makhluk Hidup. Jurnal Pendidikan IPAIndonesia. (1). 75-81.

Sari, D. P. Putra, R. Syazali, M. (2018). Pengaruh Metode Kuis Interaktif
Terhadap Kemampuan Pemecahan Masalah Matematis Mata Kuliah Trigonometri. Jurnal Pendidikan Matematika.12(2). 63-72.

Shamil. (2019). Getting Started with Quizizz.[Online] Tersedia: http://Quizizz.zendesk.com/hc/enus/articles/115000338045-GettingStarted-with-Quizizz (diakses 17 Februari 2019)

Setyanta, B. A. Murwaningtyas, C. E. (2012). Pengaruh Pemberian Kuis Terhadap Motivasi dan Hasil Belajar Siswa SMP Kanisius Kalasan Tahun Pelajaran 2012/2013 pada Materi Faktorisasi Suku Aljabar. Prosiding Seminar Nasional Matematika dan Pendidikan Matematika FMIPA UNY. 141-148.

Side, S. Sulastry, T. Supardi, R. (2017). Pengaruh Pemberian Kuis di Awal Pembelajaran pada Model Pembelajaran Inkuiri Terhadap Hasil Belajar Siswa Kelas X SMK Negeri 2 Parepare (Studi pada Materi Pokok Ikatan Kimia).

Jurna lChemica. 18(1). 26-34.Sugiyono. (2012). Metode Penelitian Pendidikan Pendekatan Kuantitatif, Kualitatif dan $R \& D$. Bandung, Indonesia: Alfabeta. 